\title{
Foraging Behaviours and Diets of Wolves in the Queen Maud Gulf Bird Sanctuary, Nunavut, Canada
}

\author{
NATHAN WIEBE,${ }^{1,2}$ GUSTAF SAMELIUS, ${ }^{1,3}$ RAY T. ALISAUSKAS,${ }^{1,4}$ JASON L. BANTLE,,${ }^{1,5}$ \\ CHRISTOFFER BERGMAN,${ }^{6}$ ROBERT DE CARLE,${ }^{1,7}$ CHRISTOPHER J. HENDRICKSON,${ }^{1,8}$ ALAIN LUSIGNAN, ${ }^{9}$ \\ KIMBERLY J. PHIPPS ${ }^{1,10}$ and JUSTIN PITT ${ }^{1,11}$
}

(Received 8 October 2008; accepted in revised form 17 February 2009)

\begin{abstract}
Predation patterns often reflect the abundance and distribution of prey although factors such as vulnerability and ease of prey capture also affect these patterns. Wolves (Canis lupus) rely primarily on ungulates throughout most of their range even though other foods can be locally and seasonally important. We combined direct observation of wolves and scat analyses to examine the foraging behaviours and diets of wolves in the Queen Maud Gulf Bird Sanctuary, Nunavut, Canada. We were especially interested in how wolves used birds (primarily geese, Chen spp.) that were nesting in large numbers and dense colonies in the sanctuary. Caribou (Rangifer tarandus), which occurred in $65 \%$ of all scats, and bird prey, found in $29 \%$, were the most common foods in scats, and behavioural observations confirmed this pattern. This study showed that caribou were the main prey of wolves in the Queen Maud Gulf Bird Sanctuary but that wolves also preyed on vulnerable and seasonally abundant foods, such as migratory birds, especially in late summer when ducks and geese were flightless during their annual remigial molt.
\end{abstract}

Key words: wolves, Canis lupus, foraging behaviour, Queen Maud Gulf Bird Sanctuary, migratory birds, vulnerability of prey

RÉSUMÉ. Souvent, les modèles de prédation sont le reflet de l'abondance et de la répartition des proies, bien que des facteurs tels que la vulnérabilité et la facilité de capture des proies exercent également une influence sur ces modèles. Les loups (Canis lupus) font principalement la prédation d'ongulés quasiment à la grandeur de leur parcours, quoique d'autres sources de nourriture puissent également être importantes selon les endroits et les saisons. Nous avons recouru à l'observation directe des loups et à l'examen des excréments pour déterminer les comportements de recherche de nourriture et les régimes alimentaires des loups du Refuge d'oiseaux du golfe Reine-Maud, au Nunavut, Canada. Nous nous sommes particulièrement intéressés à la manière dont les loups se servaient des oiseaux (surtout les oies, Chen spp.) qui nidifiaient en grands nombres et faisaient partie de colonies denses au refuge. Le caribou (Rangifer tarandus), qui se retrouvait dans $65 \%$ de tous les excréments, et les oiseaux de proie, qui se trouvaient dans $29 \%$ des cas, constituaient les sources de nourriture les plus courantes des excréments. Ces tendances ont d'ailleurs été confirmées par les observations de comportement. Cette étude nous a permis de constater que le caribou représentait la principale proie des loups du Refuge d'oiseaux du golfe Reine-Maud, mais que les loups profitaient aussi de sources de nourriture vulnérables et abondantes selon les saisons, comme les oiseaux migrateurs, surtout vers la fin de l'été lorsque les canards et les oies ne pouvaient pas voler pendant la mue annuelle des rémiges.

Mots clés : loups, Canis lupus, comportement de recherche de nourriture, Refuge d'oiseaux du golfe Reine-Maud, oiseaux migrateurs, vulnérabilité des proies

Traduit pour la revue Arctic par Nicole Giguère.

\footnotetext{
${ }^{1}$ Department of Biology, University of Saskatchewan, 112 Science Place, Saskatoon, Saskatchewan S7N 5E2, Canada

${ }^{2}$ Present address: 734 Matheson Drive, Saskatoon, Saskatchewan S7L 3Y7, Canada

${ }^{3}$ Corresponding author: gustafsamelius@hotmail.com; present address: Grimsö Wildlife Research Station, Swedish University of Agricultural Sciences, 73091 Riddarhyttan, Sweden

${ }^{4}$ Environment Canada, Prairie and Northern Wildlife Research Centre, 115 Perimeter Road, Saskatoon, Saskatchewan S7N 0X4, Canada

${ }^{5}$ Jason Leo Bantle Photography, Box 61, Christopher Lake, Saskatchewan S0J 0N0, Canada

${ }^{6}$ Fjällglimten 28, 83246 Östersund, Sweden

${ }^{7}$ Present address: 436 Campbell Drive, Grand Forks, North Dakota 58201, USA

${ }^{8}$ Present address: Chris Hendrickson Photography, 414 4th Street East, Saskatoon, Saskatchewan S7H 1J5, Canada

${ }^{9}$ Faculty of Agricultural and Environmental Sciences, McGill University, 21111 Lakeshore Road, Ste. Anne de Bellevue, Quebec H9X 3V9, Canada; present address: Department of Biology, Memorial University, St. John's, Newfoundland A1B 3X9, Canada

${ }^{10}$ Present address: Agriculture and Agri-Food Canada, Prairie Farm Rehabilitation Administration, 1011-11 Innovation Boulevard, Saskatoon, Saskatchewan S7N 3H5, Canada

${ }^{11}$ Present address: Department of Biological Sciences, University of Alberta, Edmonton, Alberta T6G 2E9, Canada

(C) The Arctic Institute of North America
} 


\section{INTRODUCTION}

Predation patterns often reflect the abundance and distribution of prey although factors such as vulnerability and ease of prey capture also affect these patterns (Begon et al., 1996; Peterson and Ciucci, 2003). Wolves (Canis lupus) rely primarily on ungulate prey throughout most of their range (Paquet and Carbyn, 2003; Peterson and Ciucci, 2003). However, other foods such as lagomorphs, beavers (Castor canadensis), birds, and fishes can be locally or seasonally important (Voigt et al., 1976; Spaulding et al., 1998; Darimont et al., 2003; Mech, 2007). Caribou (Rangifer tarandus) are the primary prey of wolves in many northern and Arctic areas (Kuyt, 1972; Stephenson and James, 1982) although arctic hares (Lepus arcticus) and muskoxen (Ovibos moschatus) can also be important foods in areas where caribou are scarce (Mech, 2005, 2007).

Wolves are opportunistic predators that prey on abundant and vulnerable prey (Paquet and Carbyn, 2003; Peterson and Ciucci, 2003). For example, wolves prey on salmon (Oncorhynchus spp.) during runs when salmon are abundant and spatially constrained (Darimont et al., 2003, 2008). Similarly, wolves often prey on weak and subordinate individuals (Mech and Peterson, 2003). Preying on smaller but abundant prey reduces the risk of injury that ungulate prey may inflict (Darimont et al., 2003, 2008). In fact, severe injuries to wolves during their pursuit of ungulates (Mech and Nelson, 1990) and even deaths (Mech and Nelson, 1990; Weaver, 1992) have been reported.

The objective of this study was to examine foraging behaviours and diets of wolves in the Queen Maud Gulf Bird Sanctuary, Nunavut, Canada. We were especially interested in how wolves used the geese that nest in great numbers in the sanctuary. Wolves in this area follow caribou and typically migrate south of the tree line in winter (Walton et al., 2001). However, since local hunters occasionally harvest wolves during winter, some must remain in the area throughout the year. We combined scat analysis and direct observations to study foraging behaviours and diets of wolves.

\section{METHODS}

The information collected in this study was obtained while conducting research on geese and arctic foxes (Vulpes lagopus) from May to July in 1992, 1994, and 2000-04.

\section{Study Area}

This study was conducted at the large goose colony at Karrak Lake $\left(67^{\circ} 14^{\prime} \mathrm{N}, 100^{\circ} 15^{\prime} \mathrm{W}\right)$ and surrounding areas in the Queen Maud Gulf Bird Sanctuary, Nunavut, Canada. The sanctuary provides important nesting grounds for several million migratory birds, especially ducks and geese (Kerbes, 1994). Karrak Lake, the largest goose colony in the sanctuary (Kerbes, 1994), consisted of about 500000 to 1 million nesting Ross's geese (Chen rossi) and lesser snow geese (Chen caerulescens) each year from 1992 to 2004 (R.T. Alisauskas, unpubl. data). The area of the colony increased from about $10 \times 10 \mathrm{~km}$ in 1992 to about $15 \times$ $20 \mathrm{~km}$ in 2004 (R.T. Alisauskas, unpubl. data). Geese arrive at Karrak Lake in late May and depart the colony shortly after hatch in early July, when they disperse throughout the sanctuary and very few geese remain in or near the colony (Ryder and Alisauskas, 1995). Geese migrate south in late August and do not return to the Arctic until mid to late May the following year. Geese go through their annual remigial molt in mid July to mid August and are flightless during this period (Ryder and Alisauskas, 1995). Karrak Lake and surrounding areas consist of gently rolling tundra that is dominated by rock outcrops, sedge meadows, and marshy areas interrupted by shallow tundra ponds (Ryder, 1972).

In addition to wolves and geese, other animals common in the area included grizzly bears (Ursus arctos), wolverines (Gulo gulo), arctic foxes, caribou, muskoxen, ptarmigans (Lagopus spp.), collared lemmings (Dicrostonyx torquatus), and red-backed voles (Clethrionomys rutilus). Arctic hares, arctic ground squirrels (Spermophilus parryii), and brown lemmings (Lemmus sibiricus) were also present in the area but only at low densities (R.T. Alisauskas, unpubl. data). Caribou were very numerous in May and early June when they were moving through the area to their calving grounds north of Karrak Lake (Gunn et al., 2000). Caribou belong to the Ahiak herd (formerly known as the Queen Maud Gulf caribou herd) and winter south of the tree line and east of Great Slave Lake (Gunn et al., 2000).

\section{Scat Analyses}

We collected scats opportunistically while studying arctic fox ecology at the Karrak Lake area from May to July in 2000-04. Scats were collected in the goose colony at Karrak Lake and in areas up to ca. $10 \mathrm{~km}$ outside the colony. We included only scats that were larger than $2.0 \mathrm{~cm}$ in diameter, elongated in shape, and had a tapered end to avoid including scats from foxes and wolverines. Fresh scats collected in spring were generally associated with wolf tracks in the snow, which helped confirm species identity. Further, we sorted scats into "fresh" $(\mathrm{n}=34)$ and "old" $(\mathrm{n}=51)$ scats. Fresh scats had not yet started to decay or become white, and these scats generally had a shiny tinge. Old scats were those that were white or showed other signs of decay (e.g., dry and weathered). We suggest that old scats were primarily from the second half of the previous summer because (1) most scats $(78 \%)$ were collected at fox dens that we visited regularly from May to July (i.e., old scats were likely deposited after our last visit in mid to late July) and (2) most wolves migrated south in winter (Walton et al., 2001). Fresh scats, in contrast, were primarily from spring and early summer (May to mid July).

We dried scats in the field and froze them at ca. $-20^{\circ} \mathrm{C}$ for 1-4 years, depending on the year of collection. We heated scats to $90^{\circ} \mathrm{C}$ for $16-24$ hours to kill potential eggs from 
Echinococcus multilocularis. Further, we removed a 2-3 $\mathrm{cm}$ long piece from old scats for a study on Echinococcus multilocularis (this was not done on scats shorter than 5-7 $\mathrm{cm}$ ). We suggest that such removal had limited, if any, effect on the analyses, as the contents of scats were very homogeneous (see results). Scats were dissected by hand and contents were categorized as caribou, muskoxen, hare, rodent, or bird prey. We made gross identifications of scat contents based on reference material collected in the field, and we summarized data as frequency of occurrence for each prey type. We examined whether prey types occurred equally frequently in scats by performing a chi-square goodness-offit test for which data were arranged by frequency of occurrence for each prey type (Proc Freq, SAS Institute Inc., Cary, North Carolina). Similarly, we examined whether prey types occurred equally frequently in fresh and old scats by a two-way chi-square test for which data were arranged by prey type and scat type (Proc Freq, SAS Institute Inc.).

\section{Behavioural Observations}

We encountered wolves on numerous occasions during our work on foxes and geese in 1992, 1994, and 2000-04. For each observation, we recorded (1) whether wolves attempted to take any food, (2) whether wolves were successful in their attempts at taking food, and (3) the type of food wolves attempted to take. Observations of wolves were made at distances ranging from ca. $100 \mathrm{~m}$ to over $1 \mathrm{~km}$, and most observations were made with binoculars or spotting scopes. Wolves occasionally responded to our presence (either by inspecting us or rushing away), so we included only behaviours during which wolves appeared to be unaffected by our presence.

\section{RESULTS}

\section{Scat Analyses}

Prey types did not occur with equal frequency in scats $\left(\chi_{(4)}^{2}=65.72, p<0.001\right)$; caribou was the most frequent prey type, occurring in $65 \%$ of all scats, followed by bird prey $(29 \%)$, arctic hare (18\%), rodents (12\%), and muskoxen (9\%) (Table 1). Similarly, prey types were not equally frequent in fresh and old scats $\left(\chi_{(4)}^{2}=11.44, p=0.02\right)$. This difference was especially prominent for caribou and bird prey: caribou occurred more frequently in fresh than in old scats, while bird prey occurred more frequently in old than in fresh scats (Table 1). The mean number of prey types per scat (for fresh and old scats combined) was $1.33(95 \% \mathrm{CL}=0.14)$, with a range of $1-4$.

\section{Behavioural Observations}

We encountered wolves on 78 occasions, and wolves took or attempted to take one or more foods on 22 of those occasions (Table 2). Most of these foraging events were directed at caribou and geese. The distance that wolves chased caribou ranged from ca. $100 \mathrm{~m}$ to more than $1500 \mathrm{~m}$, and the number of caribou that wolves pursued ranged from 1 to more than 1000 (see Table 2). In addition to wolves pursuing caribou, we often saw caribou rushing away from wolves before wolves initiated attacks. These caribou were at distances well above that at which we saw wolves initiating their attacks. The first of the two attacks on muskoxen lasted 10 minutes from the time that the wolves approached the muskoxen until they trotted away from the muskoxen (wolves rested for 10 minutes ca. $100 \mathrm{~m}$ away from the herd after the attack). The muskoxen grouped tightly as the wolves approached, and one large muskox came out to defend the others as the wolves circled the herd. Wolves did not lunge at muskoxen during this attack. The second attack on muskoxen lasted at least five minutes (we did not see the onset of the attack), during which the wolves ran around the muskoxen and appeared to lunge at the muskoxen numerous times. The muskoxen were grouped very closely together and bucked continuously, jumping around in a circular manner, as the wolves were within a few meters of them. After the attack, the wolves rested for seven minutes about $100 \mathrm{~m}$ away from the muskoxen and then trotted away from the area.

We saw wolves travelling among nesting geese on 27 occasions. All geese within ca. $20 \mathrm{~m}$ of the wolf ( $\mathrm{n}=$ $20)$ or wolves $(n=7)$ left their nests and generally settled about 50-100 m away from the travelling wolf or wolves. Wolves were often followed by geese that walked, flew, or swam behind them at distances of about $100-200 \mathrm{~m}$ in a manner described by Slattery et al. (1998). Wolves generally ignored geese when trotting through the colony, and we saw wolves rushing at geese on only three occasions (during one of which one wolf rushed at geese eight times during the same observation). All rushes covered only a few meters and were directed at geese that were late at leaving their nests. Similarly, wolves generally ignored eggs when trotting through the colony. In fact, we saw wolves feeding on eggs on only two occasions. The first time, the wolf fed on two eggs after first nudging them out of a nest and rolling them down a two-metre-high bank (presumably breaking them). The second time, the wolf fed on eggs from three different nests during the same observation. We estimate that wolves ignored well over 1000 geese and their eggs during our observations.

\section{DISCUSSION}

This study showed that caribou were the main prey of wolves in the Queen Maud Gulf Bird Sanctuary but that wolves also commonly fed on birds that nested in large numbers in the sanctuary. These patterns were similar to those in other parts of the Canadian Arctic where caribou is often the main prey of wolves (Paquet and Carbyn, 2003; Peterson and Ciucci, 2003), but they also illustrate how wolves included seasonally abundant foods such as 
TABLE 1. Frequency of occurrence (\%) of prey types in wolf scats collected at Karrak Lake and surrounding areas in the Queen Maud Gulf Bird Sanctuary, Nunavut, Canada, in 2000-04. Most scats (78\%) were collected at fox dens that we visited regularly from May to July.

\begin{tabular}{lcccccc}
\hline \hline Type of Scat and Season & Caribou & Muskoxen & Hare & Rodent & Bird & Unknown \\
\hline Fresh scats (spring and early summer) & 79 & 12 & 12 & 12 & 9 & 0 \\
Old scats (late summer and possibly winter) & 55 & 8 & 22 & 12 & 43 & 2 \\
All scats & 65 & 9 & 18 & 12 & 29 & 1 \\
\hline \hline
\end{tabular}

TABLE 2. Foraging behaviours of wolves observed at Karrak Lake and surrounding areas in the Queen Maud Gulf Bird Sanctuary, Nunavut, Canada, in 1992, 1994, and 2000-04.

\begin{tabular}{|c|c|c|}
\hline \multicolumn{2}{|c|}{ Number of Wolves } & \multirow[t]{2}{*}{ Observations } \\
\hline Caribou & & \\
\hline 12 May 2001 & 2 & Consumed back part of caribou in ca. $30 \mathrm{~min}$; caribou likely killed by wolves \\
\hline 2 July 2001 & 1 & Chased a group of 5-6 caribou, outcome of chase unknown \\
\hline 18 May 2002 & 6 & Appeared to chase caribou, first 1 and then 2 wolves split off from main group of wolves \\
\hline 31 May 2002 & 1 & Fed on caribou carcass; caribou likely killed by wolf or wolves \\
\hline 2 June 2002 & 1 & Made two short rushes for lone caribou, caribou easily escaped wolf \\
\hline 1 July 2002 & 2 & Chased ca. 80 caribou over $1.5 \mathrm{~km}$, separated one animal, outcome of chase unknown ${ }^{1}$ \\
\hline 3 July 2002 & 2 & Rushed for a herd of 5000-10 000 caribou, appeared to bite at least three caribou, outcome of chase unknown \\
\hline 6 June 2004 & 2 & One wolf made a short rush for a group of four caribou; caribou easily escaped wolf \\
\hline 4 July 2004 & 1 & Chased a group of ca. 10 caribou for ca. $300 \mathrm{~m}$; caribou easily escaped wolf \\
\hline \multicolumn{3}{|l|}{ Muskoxen } \\
\hline 31 May 1992 & 2 & Attacked a herd of 14 adult muskoxen, but did not capture any animals \\
\hline 27 June 1992 & 2 & Attacked two adult muskoxen, but did not capture any animals \\
\hline 12 June 2003 & 1 & Fed on the rumen of an almost completely consumed muskox carcass \\
\hline \multicolumn{3}{|l|}{ Geese } \\
\hline 13 June 1992 & 2 & One wolf fed on a goose carcass; unknown if goose was killed or scavenged \\
\hline 16 June 1994 & 1 & Fed on a goose carcass; unknown if goose was killed or scavenged \\
\hline 28 June 2000 & 1 & Fed on a goose carcass scavenged from fox den, bitten in hind leg by fox ${ }^{2}$ \\
\hline 17 June 2002 & 1 & Made a short rush for a nesting Ross' goose without capturing the goose \\
\hline 24 June 2002 & 1 & Fed on two eggs from a goose nest, nudged eggs out of nest and rolled them down a slope \\
\hline 1 July 2002 & 2 & $\begin{array}{l}\text { Fed on goose carcass, one wolf at the time - one wolf begged while first wolf fed, one wolf made a short rush for a nesting } \\
\text { goose without capturing the goose } \mathrm{e}^{1}\end{array}$ \\
\hline 13 June 2004 & 3 & $\begin{array}{l}\text { One wolf made eight short rushes for geese }{ }^{3} \text { and fed on eggs from three nests (unknown how many eggs from each nest) while } \\
\text { the other wolves rested }\end{array}$ \\
\hline \multicolumn{3}{|l|}{ Rodents } \\
\hline 19 May 2000 & 5 & One wolf pounced in snow, but did not capture any animal \\
\hline 13 June 2002 & 1 & Pounced in snow, but did not capture any animal \\
\hline \multicolumn{3}{|l|}{ Unknown Foods } \\
\hline 28 June 2000 & 1 & Scavenged unknown object from fox den, did not consume it, bitten in hind leg by fox ${ }^{2}$ \\
\hline 26 June 2003 & 1 & Fed on unknown small object that was found on the ground \\
\hline 23 July 2003 & 2 & One wolf fed on unknown small object that was found on the ground \\
\hline
\end{tabular}

${ }^{1}$ Occurred during the same observation.

${ }^{2}$ Occurred during the same observation.

${ }^{3}$ Six rushes were directed at nesting geese and two at geese not on their nests.

migratory birds in their diets. However, apparently it was not the abundance of birds, but rather the ease of capture that affected the rate at which wolves preyed on birds. Specifically, bird prey were more common in old scats than they were in fresh scats, which suggests that birds fell prey to wolves more frequently in late summer than they did in spring and early summer. In late summer, ducks and geese (which form the majority of birds in the sanctuary) were flightless during their annual remigial molt. Thus they were easier to capture than during the nesting period, when they could easily escape wolves by flying. Preying on temporarily vulnerable prey such as flightless waterfowl may be adaptive behaviour to avoid the risk of injury or death that is associated with attacking ungulate prey (see Darimont et al., 2003, 2008 for similar discussion). Our behavioural observations were concentrated in the period prior to the annual molt by ducks and geese; however, Arctic wolves have previously been observed to prey on flightless geese. The Canadian Wildlife Service noted such behaviour when conducting aerial surveys on Baffin Island, Nunavut, Canada (R. Kerbes, pers. comm. 2008), and so did the British Broadcasting Corporation (BBC), when filming the Planet Earth Series on Ellesmere Island, Nunavut, Canada (www. bbc.co.uk/nature/animals/planetearth). 
Caribou remains were more common in fresh scats than they were in old scats, which suggests that wolves were preying on caribou more frequently in May and early June (when caribou were returning from their winter grounds and during the calving period) than in late summer, when calves were larger and caribou were dispersed throughout the sanctuary (Gunn et al., 2000). These patterns were similar to those found in other areas where wolf predation often reflects variation in the abundance and vulnerability of their main prey (Paquet and Carbyn, 2003; Peterson and Ciucci, 2003). Wolves often made short rushes at caribou without capturing an animal, which may indicate that wolves were testing caribou (e.g., identifying weak or injured prey). Such testing may be more important in open habitats such as tundra landscapes, where it is generally more difficult to approach prey unnoticed, than in forested areas (Riginos and Grace, 2008). Such testing may also allow wolves to identify and avoid attacking aggressive individuals, thus reducing the likelihood of attacking caribou that may cause them injury.

Our behavioural observations showed that wolves largely ignored geese and their eggs during the nesting period although 500000 to 1 million nesting geese, plus their eggs, were available at the Karrak Lake colony. Wolves may have ignored nesting geese because of difficulties in capturing geese during the nesting period (see above). They may have ignored eggs because large consumption of albumen can result in biotin deficiency (Klevay, 1976). In fact, wolves may be more sensitive to albumen than arctic foxes, which can consume eggs for $50-60 \%$ of their diet without any signs of biotin deficiency (Samelius et al., 2007). Moreover, wolves appeared to be more persistent when chasing caribou and attacking muskoxen than they were when rushing for nesting geese. This persistence may largely have reflected differences in the difficulty of capturing the prey and the subsequent reward.

Scat analyses showed that wolves occasionally fed on smaller animals such as arctic hares and rodents, although these foods (especially rodents) contributed only minor portions to overall wolf diets. The relatively low contribution of these foods to overall wolf diets may have reflected their abundance (arctic hares were rare in the study area) or the low profitability of consuming them (wolves would need to spend considerable time hunting small mammals to meet their nutritional needs). Similarly, scat analyses showed that while wolves occasionally fed on muskoxen, this food comprised only a minor portion of their overall diet. The relative unimportance of muskoxen compared to caribou may be due either to their lesser abundance or to their larger size and ability to present a more formidable defence to wolves (Gray, 1970; Mech and Adams, 1999).

In summary, this study showed that wolves in the Queen Maud Gulf Bird Sanctuary were dynamic predators that appeared to adjust their diets according to prey vulnerability and ease of capture. Specifically, it appeared to be the vulnerability of birds during the annual molt, rather than their abundance, that affected the rate of wolf predation. In fact, preying on vulnerable prey such as flightless waterfowl may be an adaptive behaviour compared to preying on caribou because birds offer virtually no risk of injury or death to wolves.

\section{ACKNOWLEDGEMENTS}

This study was funded by the California Department of Fish and Game, the Canadian Wildlife Service, the Delta Waterfowl Foundation, Ducks Unlimited Inc., the Jennifer Robinson Memorial Scholarship, the Northern Scientific Training Program, the Polar Continental Shelf Project, the Science Horizon Program, the Sweden-America Foundation, and the University of Saskatchewan. We thank J. Aitaok, B. Eyegetok, and D. Stern for assistance and hospitality in Cambridge Bay and three anonymous reviewers for comments that helped improve this manuscript.

\section{REFERENCES}

Begon, M., Harper, J.L., and Townsend, C.R. 1996. Ecology: Individuals, populations and communities, 3rd ed. Boston: Blackwell Scientific Publications.

Darimont, C.T., Reimchen, T.E., and Paquet, P.C. 2003. Foraging behaviour by gray wolves on salmon streams in coastal British Columbia. Canadian Journal of Zoology 81:349-353.

Darimont, C.T., Paquet, P.C., and Reimchen, T.E. 2008. Spawning salmon disrupt trophic coupling between wolves and ungulate prey in coastal British Columbia. BMC Ecology 8:14.

Gray, D.R. 1970. The killing of a bull muskox by a single wolf. Arctic 23:197-199.

Gunn, A., Fournier, B., and Nishi, J. 2000. Abundance and distribution of the Queen Maud Gulf caribou herd, 1986-98. File Report No. 126. Yellowknife: Department of Resources, Wildlife and Economic Development, Government of the Northwest Territories.

Kerbes, R.H. 1994. Colonies and numbers of Ross' geese and lesser snow geese in the Queen Maud Gulf Migratory Bird Sanctuary. CWS Occasional Paper 81. Ottawa: Canadian Wildlife Service.

Klevay, L.M. 1976. The biotin requirements of rats fed 20\% egg white. Journal of Nutrition 106:1643-1646.

Kuyt, E. 1972. Food habits and ecology of wolves on barren-ground caribou range in the Northwest Territories. CWS Report Series 21. Ottawa: Canadian Wildlife Service.

Mech, L.D. 2005. Decline and recovery of a High Arctic wolfprey system. Arctic 58:305-307.

- 2007. Annual arctic wolf pack size related to arctic hare numbers. Arctic 60:309-311.

Mech, L.D., and Adams, L.G. 1999. Killing of a muskox, Ovibos moschatus, by two wolves, Canis lupus, and subsequent caching. Canadian Field-Naturalist 113:673-675.

Mech, L.D., and Nelson, M.E. 1990. Evidence of prey-caused mortality in three wolves. American Midland Naturalist 123:207-208. 
Mech, L.D., and Peterson, R.O. 2003. Wolf-prey relations. In: Mech, L.D., and Boitani, L., eds. Wolves: Behavior, ecology, and conservation. Chicago: The University of Chicago Press. $131-160$.

Paquet, P.C., and Carbyn, L.N. 2003. Wolf, Canis lupus. In: Feldhamer, G.A., Thompson, B.C., and Chapman, J.A., eds. Wild mammals of North America: Biology, management, and conservation, 2nd ed. Baltimore, Maryland: The John Hopkins University Press. 482-510.

Peterson, R.O., and Ciucci, P. 2003. The wolf as a carnivore. In: Mech, L.D., and Boitani, L., eds. Wolves: Behavior, ecology, and conservation. Chicago: The University of Chicago Press. $104-130$.

Riginos, C., and Grace, J.B. 2008. Savanna tree density, herbivores, and the herbaceous community: Bottom-up vs. top-down effects. Ecology 89:2228-2238.

Ryder, J.P. 1972. Biology of nesting Ross' geese. Ardea 60: $185-215$.

Ryder, J.P., and Alisauskas, R.T. 1995. Ross's goose (Chen rossii). In: Poole, A., and Gill, F., eds. The birds of North America, No. 162. Philadelphia: The Academy of Natural Sciences and Washington, D.C.: The American Ornithologists' Union.

Samelius, G., Alisauskas, R.T., Hobson, K.A., and Larivière, S. 2007. Prolonging the Arctic pulse: Long-term exploitation of cached eggs by arctic foxes when lemmings are scarce. Journal of Animal Ecology 76:873-880.

Slattery, S.M., Samelius, G., Alisauskas, R.T., Danielson, J., and Moore, F. 1998. For whom the geese toll: Aberrant or adaptive behaviour in Ross's Chen rossii and lesser snow geese Chen caerulescens caerulescens? Wildfowl 49:242-244.

Spaulding, R.L., Krausman, P.R., and Ballard, W.B. 1998. Summer diet of grey wolves, Canis lupus, in northwestern Alaska. Canadian Field-Naturalist 112:262-266.

Stephenson, R.O., and James, D. 1982. Wolf movements and food habits in Northwest Alaska. In: Harrington, F.H., and Paquet, P.C., eds. Wolves of the world: Perspectives of behavior, ecology, and conservation. Park Ridge, New Jersey: Noyes Publications. 26-41.

Voigt, D.R., Kolenosky, G.B., and Pimlott, D.H. 1976. Changes in summer foods of wolves in central Ontario. Journal of Wildlife Management 40:663-668.

Walton, L.R., Cluff, H.D., Paquet, P.C., and Ramsay, M.A. 2001. Movement patterns of barren-ground wolves in the central Canadian Arctic. Journal of Mammalogy 82:867-876.

Weaver, J.L. 1992. Two wolves, Canis lupus, killed by a moose, Alces alces, in Jasper National Park, Alberta. Canadian FieldNaturalist 106:126-127. 